\title{
An Unusual Balanced Reciprocal Translocation in Several Members of a Family
}

\author{
PATRICIA L. MONTELEONE, JAMES A. MONTELEONE, and JOAN GRZEGOCKI \\ From Saint Louis University School of Medicine; and Cytogenetics Laboratory, Cardinal Glennon Memorial Hospital \\ for Children, Saint Louis, Missouri 63104, U.S.A.
}

Chromosome abnormalities in structure as well as number have often been found to be associated with congenital anomalies in humans. Numerous genetic mechanisms have been postulated to explain the cytogenetic alterations.

Wallace and Anderson (1964) reported a patient with numerous congenital anomalies whose chromosomal analysis revealed 45 chromosomes with a translocation deletion involving members of the $D$ and B Groups. Bray and Ann Josephine (1964) described an infant with severe mental and physical retardation whose karyotype comprised 46 chromosomes with an unusually long B chromosome and suggested that it represented a translocation involving members of the $B$ and $D$ groups of chromosomes. There have been 11 other reports describing long unpaired B group chromosomes without evidence or involvement of the $\mathrm{D}$ group chromosomes.

We report here results of clinical, biochemical, and cytogenetic studies of a 16-year-old white girl with multiple congenital anomalies and a complex cytogenetic aberration involving chromosomes of the $B$ and D groups carried in part by two other phenotypically normal members of her family.

\section{Case Report}

A 16-year-old white girl was referred for cytogenetic studies because of an unusual facies and multiple congenital anomalies. She was the first-born of a 20-yearold mother and 22-year-old father. There was no history of known exposure to infectious disease, radiation, or drugs during pregnancy. Gestation, labour, and delivery were described as normal. Birthweight was $2381 \mathrm{~g}$. Numerous congenital anomalies were noted at birth: namely, congenital heart disease, kyphoscoliosis, three-jointed thumbs, syndactyly, and an unusual facies. At 6 years, the patient underwent repair of an interventricular septal defect; at 7 years, she had a resection

Received March 26, 1969. of the external rectus eye muscle and recession of the internal rectus, and correction of thoracic scoliosis was done at the age 13 years. The patient has conspicuous mental and physical retardation. There is no family history of mental retardation or congenital anomalies (Fig. 1). The patient has two sibs, 10 and 13 years of age respectively, who are healthy. There was no history of miscarriages.

Physical examination showed a thin short white female with a weight of $32 \mathrm{~kg}$. and a height of $142 \mathrm{~cm}$. Her head was flattened in the A-P diameter and she had a long triangular-shaped face. The ear canals were patent and tympanic membranes normal. No epicanthal folds or coloboma were present. The nose was prominent with a narrow space between the anterior root and uppe lip. Her palate was high arched. Her neck was long with no webbing (Fig. 2). Her chest was symmetrical, the precordium was quiet, and there was no significant heart murmur. Her femoral pulses were full bilaterally. Her blood pressure was $110 / 80 \mathrm{~mm} . \mathrm{Hg}$. There was kyphoscoliosis present with surgical scars over the area. External genitalia were normal and all female secondary sex characteristics were present. The fifth fingers bilaterally had inward curvature of the distal phalanx; thumbs bilaterally had three joints and were thin, tapering, resembling a finger (see Fig. 3). There was increased space between the first and second toes bilaterally. Syndactyly was present between the second and third toes. The child had no hyperextensibility (Fig. 4).

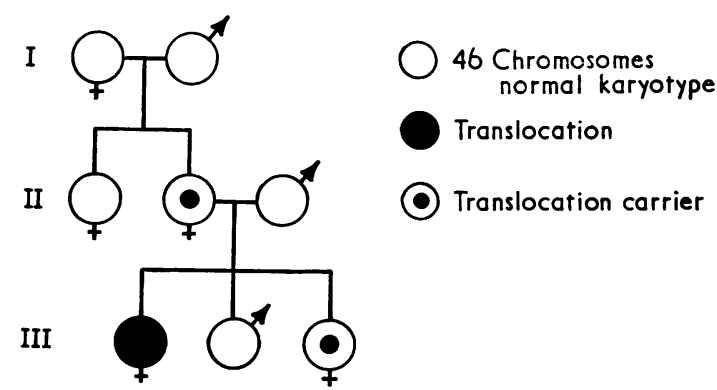

FIg. 1. Pedigree of family. 


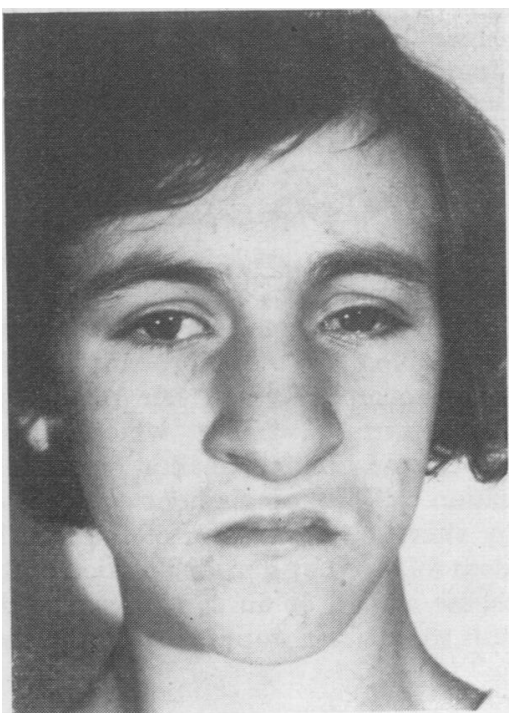

FIG. 2. The face of the patient.

Neurological examination was within normal limits. A Stanford-Binet test at 7 years of age showed her IQ to be 36 ; the WISC test showed verbal IQ of 56 ; performance IQ was below 44 and full scale IQ below 46 .

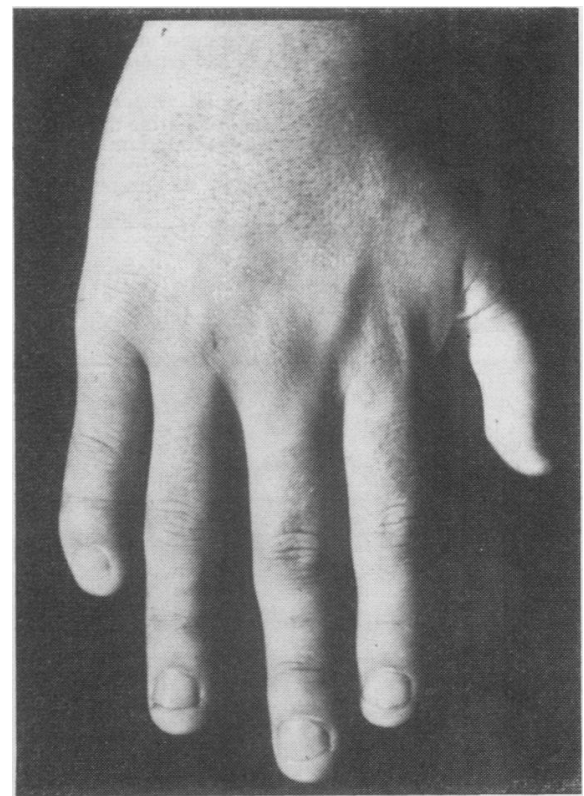

FIg. 3. Right hand of the patient showing the thumb with two flexion creases and inward curvature of the distal phalanx of the fifth digit.

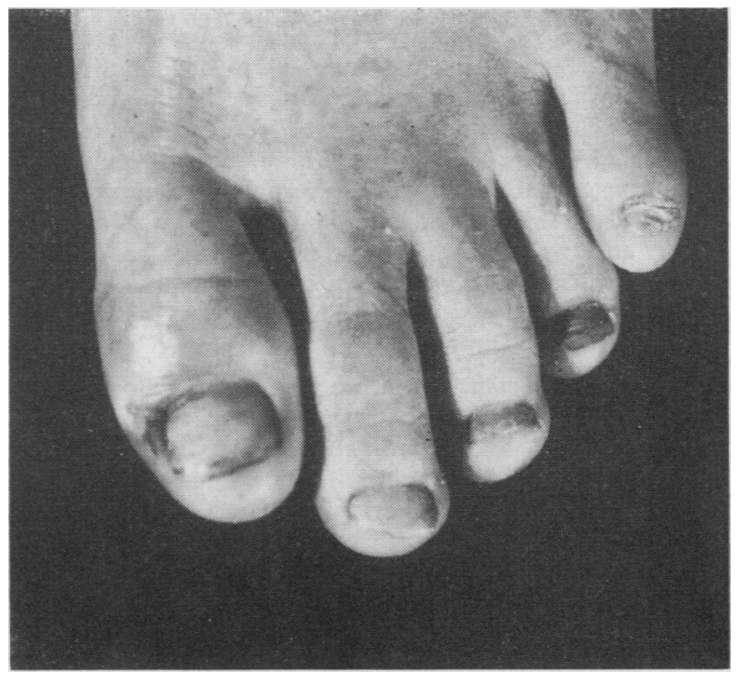

FIG. 4. Left foot showing increased space between first and second digits, syndactyly between second and third toes, and the unusual shape of the digits.

\section{Laboratory Data}

Normal routine laboratory findings included haematocrit, haemoglobin, WBC, differential, and urinalysis. Serum calcium, serum phosphorus, total serum protein, albumin, total globulin, $\alpha_{1}$-globulin, $\alpha_{2}$-globulin, $\beta$-globulin, and $\gamma$-globulin were all within normal limits. An electrocardiogram was normal except for positional changes due to kyphoscoliosis. A chest $x$-ray at the present time shows the heart to be within normal limits with normal pulmonary vasculature. There is congenital absence of the right first rib. Films of the spine showed scoliosis.

\section{Cytogenetic Studies}

The buccal smear showed $72 \%$ of the cells to contain sex chromatin. Chromosome counts on a peripheral blood sample showed that 93 of 100 cells counted had 47 chromosomes. All cells counted contained 5 D chromosomes. In addition, the long arm of one group $B$ chromosome was unusually long; two minute chromosomes were also present, both of which appeared satellited and one appeared to have satellites on both arms $(47, \mathrm{XX}, \mathrm{D}-, \mathrm{t}(\mathrm{Bq}+; \mathrm{Dq}-)$ mat,marpsqs +$)$. The sex chromosomes were normal The karyotype is shown in Fig. 5. Chromosomal analysis on a fibroblast culture established from a skin biopsy (Monteleone, Durst, and Cherry, 1968) was identical to that of peripheral blood. Analysis was done on the second subculture two months after the start of the primary culture. Fifty karyotypes of cells with 45 chromosomes showed the two centric fragments and the unusually long $B$ chromosome.

Chromosomal analysis on peripheral blood cultures of the parents and both sibs revealed abnormalities in the 
mother and the female sib. Of the 100 maternal metaphases, 95 had 46 chromosomes, with $5 \mathrm{D}$ chromosomes, one of which was unusually small and had satellites on one side of the centromere, along with the unusually long B chromosome similar to the proband's cells $(46, \mathrm{XX}, \mathrm{D}-, \mathrm{t}(\mathrm{Bq}+; \mathrm{Dq}-)$. There was a normal female sex chromosome pattern. The female sib's karyotype is identical to that of the mother (Fig. 6). Cells of the father and the male sib showed normal male karyotypes. Chromosome counts are shown in Table I.

\section{Gene Marker Studies}

Several studies attempted to localize specific genes to the D chromosome. The results of haptoglobin, transferrin analysis, and blood grouping in the family are shown in Table II. A normal inheritance pattern of all markers was found. Inheritance of red blood cell acid phosphate, phosphoglucomutase, G6PD, 6PGD, GSR, and alkaline phosphatase was normal. In addition, blood samples were tested for GM (1), GM (2), GM (3), GM (5), GM (6), GM (13), GM (14), GM (21), and Inv (1).
The pattern of inheritance was not unusual. Dermatoglyphs showed axial triradii on each palm to be within normal limits. Five digital axial triradii were present. The patterns of the fingers showed 10 ulnar loops to be present on the fingertips.

\section{Discussion}

All the cytogenetic evidence suggests that a reciprocal translocation has occurred between $\mathrm{Dq}$ and $\mathrm{Bq}$ in the mother's cells so that she has a completely balanced complement. The proband has the same chromosome complement as her mother plus an additional centric fragment which presumably represents an additional smallest product of the translocation. This complement could have come about by alternate segregation of the translocation multivalent followed by non-disjunction of the small chromosome at $\mathrm{M}^{\mathrm{II}}$ or an early cleavage division. The result would be a duplication of the short arm

TABLE I

CHROMOSOME COUNTS ON THE FAMILY

\begin{tabular}{|c|c|c|c|c|c|c|c|}
\hline \multirow{2}{*}{ Tissue } & \multirow{2}{*}{ Subject } & \multicolumn{5}{|c|}{ Chromosome Counts } & \multirow{2}{*}{ Karyotype Analysis } \\
\hline & & 43 & 44 & 45 & 46 & 47 & \\
\hline \multirow{4}{*}{ Blood } & Proband & 1 & 0 & 3 & 94 & 93 & \multirow{4}{*}{$\begin{array}{l}47 \text { chromosomes with } 2 \text { chromosomes of D group unusually small; } 1 \text { of these chromosomes } \\
\text { has satellites on short arm side of centromere and } 1 \text { chromosome has satellites on both } \\
\text { sides of centromere; there is } 1 \text { B chromosome which has unusually long arms } \\
7 \text { cells with fewer than } 47 \text { chromosomes showed random loss of chromosomes } \\
46 \text { chromosomes (XY)-normal; } 6 \text { cells with fewer or more than } 46 \text { chromosomes showed } \\
\text { random loss of chromosomes } \\
46 \text { chromosomes with } 1 \text { chromosome of D group unusually small, with satellites on short } \\
\text { arm side of centromere; there is } 1 \text { B chromosome which has long arms that are unusually } \\
\text { long; } 5 \text { cells with fewer or more than } 46 \text { chromosomes showed random loss of chromo- } \\
\text { somes } \\
46 \text { chromosomes with } 1 \text { chromosome of D group unusually small, with satellites on short } \\
\text { arm side of centromere; there is } 1 \text { B chromosome which has long arms that are unusually } \\
\text { long; } 4 \text { cells with fewer or more than } 46 \text { chromosomes showed random loss of chromo- } \\
\text { somes } \\
46 \text { chromosomes (XY)-normal; } 5 \text { cells with fewer or more than } 46 \text { chromosomes showed } \\
\text { random loss of chromosomes }\end{array}$} \\
\hline & Mother & 0 & 2 & 1 & 95 & 2 & \\
\hline & Female sib & 0 & 0 & 3 & 96 & 1 & \\
\hline & Male sib & 2 & 1 & 1 & 95 & 1 & \\
\hline Skin & $\begin{array}{l}\text { Proband } \\
\text { Father } \\
\text { Mother } \\
\text { Female sib } \\
\text { Male sib }\end{array}$ & $\begin{array}{l}0 \\
1 \\
0 \\
0 \\
0\end{array}$ & $\begin{array}{l}0 \\
0 \\
2 \\
3 \\
2\end{array}$ & $\begin{array}{l}1 \\
1 \\
2 \\
2 \\
1\end{array}$ & $\begin{array}{r}2 \\
48 \\
45 \\
44 \\
47\end{array}$ & $\begin{array}{r}47 \\
0 \\
1 \\
1 \\
0\end{array}$ & Same as peripheral blood \\
\hline
\end{tabular}

RESULTS OF RED BLOOD CELL ANTIGEN STUDIES, SERYM

\begin{tabular}{|c|c|c|c|c|c|c|c|c|c|c|c|c|c|c|c|c|c|c|c|c|c|c|}
\hline & \multicolumn{2}{|c|}{$\mathrm{ABO}$} & \multicolumn{8}{|c|}{$\mathbf{R h}$} & \multicolumn{5}{|c|}{ Kell } & \multicolumn{2}{|c|}{ Duffy } & \multicolumn{2}{|c|}{ Kidd } & \multicolumn{2}{|c|}{ Lewis } & $\frac{0}{3}$ \\
\hline Subject & $\mathbf{A}$ & B & C & D & $\mathbf{E}$ & c & e & $f$ & V & $\mathrm{C}^{\mathrm{w}}$ & $\mathbf{K}$ & $\mathbf{k}$ & $\mathrm{Kp}^{\mathrm{a}}$ & $K p^{b} J^{a}$ & $\mathrm{Js}^{\mathrm{b}}$ & $F y^{2}$ & $\mathrm{Fy}^{\mathrm{b}}$ & $\mathbf{J k}^{\mathbf{a}}$ & $\mathbf{J k}^{\mathbf{b}}$ & $\mathbf{L e}^{\mathrm{a}}$ & $\mathbf{L e}^{b}$ & 志 \\
\hline Father & $\begin{array}{c}\mathbf{A}_{2} \\
+\end{array}$ & - & + & $\stackrel{+}{\mathrm{D}^{\mathrm{u}}}$ & - & + & + & & - & - & - & + & + & + & - & - & + & - & + & + & - & $\stackrel{b}{\omega}$ \\
\hline Mother & $\overline{\mathbf{A}_{2}}$ & - & - & - & - & + & + & & - & - & - & + & - & + & - & + & - & + & + & - & + & q \\
\hline Patient & + & - & + & + & - & + & + & & - & - & - & + & + & + & - & + & + & - & + & - & + & 量 \\
\hline
\end{tabular}

* PGM = phosphoglucomutase ; 6PGD =6-phosphoglucose dehydrogenase; G6PD = glucose-6-phosphate dehydrogenase; GSR = glutathị̂ne 


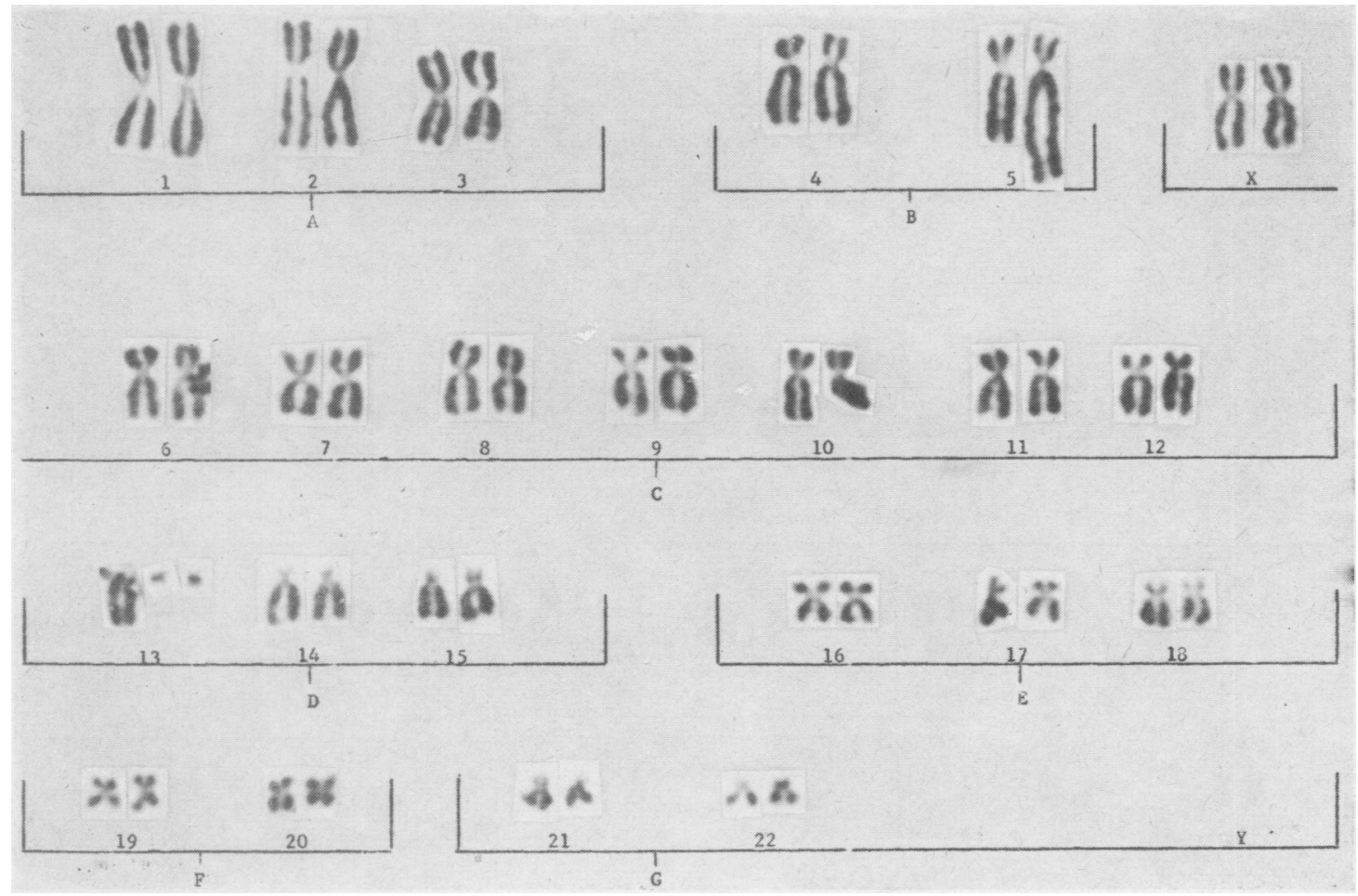

FIG. 5. Karyotype of the patient's cells from peripheral blood.

of the $\mathrm{D}$ chromosome and very short portion of the long arms of the B chromosome. Such small duplications might lead to the phenotype observed but might also, however, have no relation to the chromosomal abnormality.

It is not surprising that the B group chromosomes are involved since Shaw, Cohen, and Hilderbrandt (1965) have suggested that a specific distal segment of a B chromosome is particularly susceptible to breakage and exchange because of its heterochroma- tic nature. It has frequently been noted that chemically induced breakages are seen in this chromosomal area. If clinical similarity to known trisomic syndromes were present, this could serve as evidence for a partial trisomy. The doubly satellited centric fragment tends to make this possibility remote. The female sib has obviously inherited the same pattern as her mother.

The haptoglobin study was of particular interest since Gerald et al. (1967) and Hustinx, Bijlsma, and

FACTORS, SERUM PROTEIN GENOTYPING, AND ENZYME STUDIES

\begin{tabular}{|c|c|c|c|c|c|c|c|c|c|c|c|c|c|c|c|c|c|}
\hline \multicolumn{4}{|c|}{ MNS } & \multicolumn{2}{|c|}{ Lutheran } & \multirow{2}{*}{$\frac{\text { Diego }}{\mathrm{Di}^{\mathrm{a}}}$} & \multirow{2}{*}{$\frac{\begin{array}{c}\text { Sex } \\
\text { Linked }\end{array}}{\mathbf{X g}^{\mathbf{a}}}$} & \multicolumn{2}{|c|}{ Serum Groups } & \multicolumn{6}{|c|}{ Red Cell Enzymes } & \multirow[t]{2}{*}{$\mathrm{Gm}$} & \multirow[t]{2}{*}{ Inv } \\
\hline M & $\mathbf{N}$ & $\mathbf{S}$ & s & $\mathrm{Lu}^{\mathrm{a}}$ & $\mathrm{Lu}^{\mathrm{b}}$ & & & $\begin{array}{l}\text { Hapto- } \\
\text { globin }\end{array}$ & $\begin{array}{l}\text { Trans- } \\
\text { ferrin }\end{array}$ & PGM* & $\begin{array}{c}\text { Acid } \\
\text { Phospha- } \\
\text { tase }\end{array}$ & 6PGD* & G6PD* & GSR* & $\mathrm{AK}^{*}$ & & \\
\hline+ & + & + & + & - & + & - & + & $2-1$ & C & $1-1$ & BA & A & B & $\begin{array}{l}\text { Usual } \\
\text { type } \\
\text { Usual }\end{array}$ & $1-1$ & $1,2,21$ & -1 \\
\hline
\end{tabular}

reductase; $\mathbf{A K}=$ adenylate kinase. 


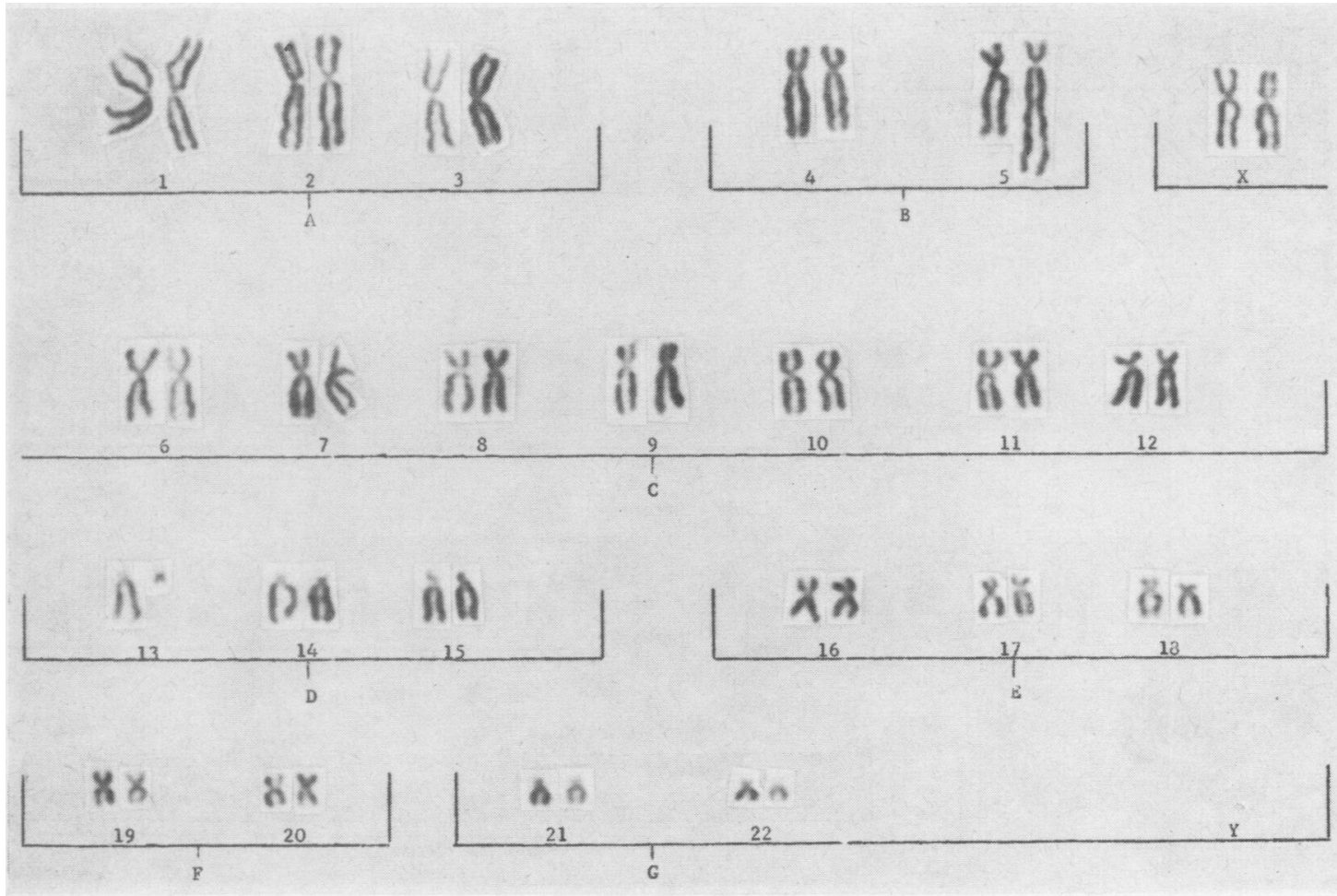

Fig. 6. Karyotype of the mother's cells from peripheral blood; it is identical to that of the female sib.

Nijenhuis (1965) have suggested that the gene for haptoglobin might be located on a $\mathrm{D}$ chromosome.

\section{Summary}

A 16-year-old girl with physical and mental retardation with multiple congenital anomalies has 47 chromosomes with 5D chromosomes; two minute chromosomes were also present, one of which appeared doubly satellited; in addition, the long arm of one B chromosome was unusually long. The karyotype of the cells of this child's mother and female sib shows 46 chromosomes with six chromosomes in the D group, one of which is unusually small and in addition, a very long chromosome in the B group similar to the proband.

The most likely explanation is that a reciprocal translocation has occurred in the mother, and the proband shows the same chromosome complement as her mother plus an additional small chromosome which apparently represents an additional smallest product of the translocation.

Many gene marker studies were performed on the patient and other family members in an attempt to localize genes to specific chromosomes. These all showed normal patterns of inheritance.

The authors wish to thank Dr. Eloise Giblett for the gene marker studies; Dr. Arthur Steinberg for the serum protein genotyping; Dr. Janet Rowley for autoradiography; and Dr. James Donahoe for referring the patient. In addition, we wish to acknowledge the technical assistance of Sister Frances Ann Lackman and Mrs. Charlotte Hill.

\section{REFERENCES}

Bray, P. F., and Sister Ann Josephine (1964). Partial autosomal trisomy and translocation. f. Amer. med. Ass., 187, 566.

Gerald, P. S., Warner, S., Singer, J. D., Corcoran, P. A., and Umansky, I. (1967). A ring D chromosome and anomalous inheritance of haptoglobin type. F. Pediat., 70, 172.

Hustinx, T. W. J., Bijlsma, J. B., and Nijenhuis, L. E. (1965). Localization of haptoglobin and ABO. Nature (Lond.), 207, 327.

Monteleone, P. L., Durst, J., and Cherry, J. D. (1968). Simplified culture of human skin fibroblasts for chromosomal analysis. Hlth Lab. Sci., 5, 257.

Shaw, M. W., Cohen, M. M., and Hilderbrandt, H. M. (1965). A familial $4 / 5$ reciprocal translocation resulting in partial trisomy $B$. Amer. F. hum. Genet. 17, 54.

Wallace, C., and Anderson, I. F. (1964). Group B/D translocation chromosome in a case with stigmata of the D trisomy. S.Afr. med. F., 38, 352. 